\title{
The Question of Desire in Singlehood and Marriage: A Critical Reading of Eating Wasps by Anita Nair
}

\author{
Dr. Navya V.K.
}

Assistant Professor, Department of English, KMM Govt. Women’s College, Kannur, Kerala, India

\begin{abstract}
Anita Nair's Eating Wasps (2018) explores everyday lives of ten women, who are fighting their own battles with different facets of patriarchy. This feminist fiction presents the issues of contemporary women in all its complexities. This paper focuses on two characters (Urvashi and Sreelakshmi) who functions as the prominent narrative voices of their own stories. These female characters, who are separated by more than half a century, are taking up the agency to move ahead with their desires against the current of societal pressures. This critical analysis explores what happens to these women when they act on their desires, in the context of their position insideloutside the institutions of marriage and family. This paper proposes that both the suicide of Sreelakshmi (which appears like a flight), and Urvashi's confrontation of her stalker (which appears like a fight) can be read as the acts of resistance that reinforces both their agencies and unapologetic nature of their desires.
\end{abstract}

Keywords-Desire, Agency, Female Sexuality, Marriage, Singlehood, Patriarchy.

\section{INTRODUCTION}

Anitha Nair's Eating Wasps narrates the stories of ten women whose cases serve as a specimen on how women struggle in a society that favours male values. Women in this fiction, hailing from different socio-cultural background and age groups were the subjects of a spectrum of abuses and discriminations ranging from acid attack (Najma) to cyber stalking (Urvashi). The commonality of these characters is that they were driven to the cliffy edges of their lives by the patriarchal society for choosing to follow the route of their desire. Most of these characters refuse to succumb to the norms of patriarchal institutions and confront the world unapologetically instead of passively allowing the society to victimise them.

This novel foreground the issues of female desire and agency. The structures of patriarchy deny women the freedom to exercise their choices and freedom. In a male dominated society, female agency and desire are restrained so as to maintain the authority of men over women. Female desire has been viewed with scepticism, and is often seen as a dangerous thing. In a study on female desire Carol Dyhouse(2017) comments on the consequences of expressing a woman's desires as : “for a woman, giving went to passion has always carried serious risks, quite aside from the physical risk of unwanted pregnancy. The social cost of being labelled unfeminine-or being seen as a loose of fallen woman-has been high." In a patriarchal society, a woman who expresses her desire and sexuality is seen as an unacceptable figure and the society often tries to repress such expressions of female desire. In this novel, the protagonists are two women who entered into the 'forbidden' realm of desires through their conscious choices. These characters come from different temporal and social situations but they are positioned within the complex matrix of social and cultural realities. Desire and sexuality of women are suppressed within the institution of family, which in turn suggests that the expression of female desire is not liberated from the clutches of societal pressures and expectations whether they are inside or outside the institution of marriage.

\section{THE QUESTION OF DESIRE AND AGENCY IN MARRIAGE AND IN SINGLEHOOD}

Sreelakshmi, lived in the sixties, was a very ambitious young woman and she chose to shelve her marriage for her career. Throughout her life, she has exercised her agency and freewill to decide how her life should move. She faces oppositions from family and society as she pursued her own desires. The friction 
between individual desire and patriarchal societal expectation resulted in her suicide. On the other hand, Urvashi's entanglement with the questions of desire and agency are situated within the institution of marriage. Urvashi, a married working woman from Bangalore, faces problems as she tries to seek desire outside of her marriage as she found her desire dried up in a so-called happy marriage. The situation gets complicated as her lover turned as a stalker in cyberspace. This analysis will focus on the tension between female desire and societal expectations by exploring the trajectories of female agency and desire as represented through the characters of Urvashi and Sreelakshmi.

Sreelakshmi (her right index finger bone) becomes the ghost narrator who witnesses the lives of different women visiting or working in the Nila resort in Kerala. Her lover Markose recovers this finger bone from her funeral pyre, secretly keep it as a souvenir in his wooden almirah and after many years, Shyam has purchased this shelf as an antique piece to furnish the Nila resort. The invisibility of the narrator is symbolic of the marginal status she occupied as a single woman and writer in the society. She says in the prologue:

Once, I had a name: Sreelakshmi. Once I was a woman. Once, I was a writer whose stories evoked love as much as disgust, inciting anger as often as they offered solace, a writer whose words sawed their way through the conventional. Once I had withstood the sting of wasps. But when I died, I was reduced to a forgotten bone, a ghost of her former self (4)

The Wasp in the title is central to the signification of her character: as a child she was bold enough to eat a wasp alive hoping to get the taste of honey in her mouth, but she subsequently realises that wasp has nothing to do with honey. The girl grew up as a strong and independent woman who has a very clear vision about life. She went for what she wants in her life, from her education to career and from singlehood to an affair. With the same passion of the girl who ate a wasp, she fell for a married man and advanced to write about her desire. These decisions met with strong opposition from the society. Ironically, in her afterlife existence, the independent woman whose success and visibility disturbed the male dominated society was made marginal by her lover Markose who continued to keep her in a secret safe for many decades.

Sreelakshmi was a good academic and intellectual who embraced singlehood as a life choice. The sole supporter of her choices was her father who encouraged her to pursue her Masters in Zoology from Banaras Hindu
University despite of strong opposition from her family and society. Her elder sisters were "married off" at the age of sixteen and there was constant pressure on her to follow the 'expected' path as a woman. She has no intention of setting up a family life for her and her ambition was to become a lecturer and a writer.Sreelakshmi was considered as a "damaged good" by the people around her because she remained unmarried. As a writer and as a lecturer, she was a successful woman but the society was not ready to accept an achieving person who defies the traditional roles (of wife and mother) conferred on women by the society and they find satisfaction by devaluing and harassing her. When singlehood in men writers are celebrated and worshipped, the woman writer receives no adoration for her singlehood.Singlehood of Sreelakshmi was either viewed with contempt or with suspicion even when she achieves considerable success in her career as a writer and as a lecture.

As a writer also she identifies her 'outsider' position in the literary landscape. Her expectations regarding a writing career and her experiences as a writer were quite different. Even after securing a prestigious Academy award, she could not find positive reception from the literary circle which was peopled by male writers and critics. The patriarchal values are embedded in the intellectual world of writing which was suppose to stand above the prejudice of the society. She describes the experience of disillusionment after winning the Academy award as follows:

I discovered adulation. I discovered what it was to be lionised. I discovered spite. Fierce competitiveness, mockery even. But I didn't find the companions I sought-the conversations on literary matters, the artistic process and the selfdoubts, the deconstruction of a novel or a poemall of it remained a figment of my imagination. Nothing much had changed from the time I ate wasp thinking that it was a bee full of honey (209)

As a budding and ambitious writer, she was disappointed with the coldness and distancing of the literary world. She could not find an intellectual companionship she longed for, as the space was not prepared to accommodate a female intellectual.

For Sreelakshmi, her writing career hits a rough patch asshe chooses to involve her body and desire in her writings. The novel titled as Letters to a Man Never Met was based on her romantic involvement with Markose and as a writer she never hesitates to write about her private experiences of desire or sexuality. Sreelakshi received awards when she wrote about typical and accepted subjects 
but the decision to explore her desire, body and sexuality through writing changes the picture. As Helen Cixous (1974) proposes, a woman writing her body is defying objectification of the society and this very act threatens the patriarchal society. According to her, there is a very close relationship between women's bodies and their writing and that both have been repressed by men for a very long time.

The public responses and rejections she faced was a response to a woman writing with and about her body. The publication of the serialised novel provokes the people around her - students, colleagues, family-and they react to her with hostility and contempt. A woman who writes openly about her desire and sexuality is a problematic that the male-dominated society can't digest.The kinds of hostile responses include people whispering around her, the paper rocket thrown to her with a sexual image in it, cold fight of her mother, threats from relatives etc. She describes the experience from college as: "My male colleagues gave me the once-over without even bothering to be circumspect about it. My older male students were like a pack of hyenas circling around me. As for the women, both colleagues and students, they hummed like needled wasps. Giant wasps who sought to paralyse me forever."(245)Apart from these everyday humiliations, her house owner asked her to vacate the rented home and her prospective research guide turned down her once approved research proposal.

Singlehood of the woman is degraded with words like "spinster" and sexual desire for a single woman is not approved by the patriarchal society. When the accidental encounter with Markose, the married priest, develops into a relationship Sreelakshi finds comfort in the care and affection of a man for the first time. She finds it as an escape routefrom her loneliness and from the mundanity of her everyday life. Her intellectuality and independence was a barrier for her to find a suitable partner as these were not the 'typical' qualities expected from women in a patriarchal society.Once she decided to pursue the man she found, she expresses her desires as,"But to him, I would go again and again. My desire was insatiable. My sex thrummed like it never had before" (225). She asserts both her right to sexual choice and the right of body to pleasure. She adopts a conscious choice in exercising her sexual liberty. Markose's act of betrayal also resonates with reducing woman as body and that may be the reason for him to run away from the Madras hotel after making love with her. Her suicide owes more to his unaccountability to her desires more than the other societal pressures that accumulated on her as a woman.

Urvashi is a modern woman who lives in the contemporary situation which is different in many aspects from the period of Sreelakshmi's life(1960s). The question is how the institution of marriage defines and limits female sexuality and desire. At turning 51, she finds herself deprived of all desires and she was bound to her marriage only by duty. She asks her husband Mahesh about herself and he replies, "I see a beautiful woman; my wife and the mother of my children. I see a successful journalist; I see a woman who runs the marathon and can drink a man under the table" (44) - a definition in which she couldn't find satisfaction. Urvashi is married to Mahesh but her 'happy marriage' dries up her desires and she sets out to seek it outside of marriage but that attempt turns out to be an unsatisfactory experience for her. It did not develop into any life fulfilling experience but was limited to sex and her lover turned out to be a stalker when she decided to quit the relationship. The experience of being stalked was described as, "each time she blocked his number, he appeared in new guide, her stalker, her very own tenheaded Ravana. You couldn't chop off one head and hope he would be dead and gone. He would surface again and again." (74)

Cyberstalking is an illegal activity where a stalker collects all the information about the victim both by watching and following a woman's or man's online activity. Cyberstalking is a form of harassment against woman and in this case, the stalker is denying Urvashi the right to reject or break up with him. He is constantly invading to her privacy and demands her to get back to the relationship. His threats and hate messages drive her mad and she finds it hard to escape from the stalker or to remove him from her personal digital space even after changing her phone number. Aravind Balakrishnan (2019) categorise this type of relationship as Simple obsessional where the victim and the perpetrator had a prior relationship and the perpetrator uses stalking as a means to coerce the victim back to the relationship. Here the victim was initially forced to escape to some distance place like the resort and she keeps her phone switched off fearing the messages she has been receiving from the stalker. Eventually she refuses to be apologetic about her choices and confront the stalker to declare her firm decision to move away from him. So, the questions of agency and desire for both of these women are entangled in the power structures of patriarchy that is antipathic to the free choices of women but both these candidates raise opposition to subjugation, remain unapologetic about their desires and refuses to be victimised by the male-dominated society.

\section{SUICIDE OR CONFRONTATION: RESPONDING TO THE DOUBLE STANDARDS OF PATRIARCHY}


Sreelakshmi ends her life in her mid-thirties and the rationale behind her choice was an enigma for the world. The world which was previously unsympathetic to her talents or sufferings displayed shock on her demise and even as a dead body, she is assuming the role of a sarcastic and detached narrator who is critical of the pretentions of people who pays respect to her body. She narrates, "an ordinary woman had become a legend, a tragic heroine, and it was the nature of my death that had turned me into someone extraordinary in their eyes. I was Kerala's Virginia Woolf." (1)

The irony of this declaration of freedom from the shackles of oppression was that he could not find closure even after death because her ex-lover Markose took her right index finger from the funeral pyre and kept it hidden in a velvet lined case within a cupboard in his home. Keeping the fingerbone in a secret safe can be seen as an act of metaphoric domestication of women inside home. But, the choice of index finger instead of the ring finger is an intriguing choice as the first one represents power, agency and leadership whereas the second represents marriage and family. So, what is left of her in the world is her power and agency that makes her the ghost narrator after half a century.

Sreelakshmi opts for suicide rather than succumbing to the choices the society have offered her. She could have settled into a marriage which her mother and relatives would have arranged for her or she could have withdrawn her publication of the controversial novel in order to go back to the comfort zone, but she deliberately discard these options expected of her from the patriarchal familial and literary circle and chooses to end her life without losing her agency or identity. Like the other decisions she had made in her life- what to study, where to study, not to marry or to have an affair with a married man- the final decision about her life was her own choice. Hence her suicide can be understood as a protest against the restrictions placed on her career and sexuality.

For Urvashi, her attempts to explore her desire was met with success but she faces the hypocrisy of her own friends when she chooses to do so.Her friends, who used to talk aloud about turning into extramarital relationships for happiness, reveals their double standards when she actually resorts to a man. But she was unapologetic about her decisions and she speaks up to him that her desire for him is no more and she wants to break up with him. When he tried to humiliate her for having a sexual relationship with him, she "refused to be shamed into submission" (160) and asks him to move on as she feels nothing for him. Urvashi was one woman who moved ahead with her desires and she never hesitate to end both her passionless marriage and possessive extramarital affair when she was suffocated within their claustrophobic hold.

\section{Conclusion}

Sreelakshmi and Urvashi were two educated and employed women who suffered from the hypocritical double standards of a male-dominated society. They lived in two different period of time, Sreelakshmi in the 1960s and Urvashi in the present but the common ground that unites them in the fiction is the oppression and devaluation they suffered from the male dominant culture. Even the time gap between them was not sufficient to erase the problems of marginalization and the burden of gender expectations from the outside world. Rather than living a life bereft of love or desire, one protagonist opts for suicide and the other chooses to walk out of a possessive relationship without yielding to the pressures of her lover's threat.

The crisis they encounter in their respective lives stems from their desire and sexuality. When Sreelakshmi decides to fall for a married priest and acted upon her desire, the cowardice and hypocrisy of her partner drives her to end her life but she never felt guilty about her desires. Similarly, as a writer, when she writes about her own body and desires, the literary world shuns her but she was unremorseful about her choices and she never step back from writing her body. This defying of norms and restrictions placed on her by the patriarchal structures results in tensions, however this paper argues how the act of ending her life serves not as an escape but as an act of protest and resistance. In the case of Urvashi, who tries to fulfil her desires and needs of sexuality outside of her marriage, the new relationship burdens her with possessiveness and humiliate her with stalking. Though her initial response was to escape from the situation, she finally confronts her problems and the final choice to confront her fears and to walk out of the toxic relationship is clearly an assertion of her agency as a woman. So, both these female narrators present a critique of the societal pressures accumulated on women through marriage, family and society and they successfully negotiate with the patriarchy by asserting their agency, desire and sexuality.

\section{REFERENCES}

[1] Balakrishnan, Aravinth. " Cyber Stalking : Challenges In Regulating Cyberstalking At The Cyber Space." http://legalserviceindia.com/legal/article-214-cyber-stalkingchallenges-in-regulating-cyberstalking-at-the-cyberspace.html Accessed 1 August 2020. 
International Journal of English Literature and Social Sciences, 5(4)

Jul-Aug 2020 /Available online: https://ijels.com/

[2] Cixous, Helene. " The Laugh of the Medusa." Trans by.Cohen Keith and Paula Cohen. Signs. Vol. 1, No. 4 (Summer, 1976), pp. 875-893.

http://www.jstor.org/stable/3173239 Accessed 27/10/2010 18:11

[3] Dyhouse, Carol. "Why are We So Afraid of Female Desire?" Literary Hub. 1 June 2017,https://lithub.com/why-are-we-soafraid-of-female-desire/LiteraryHub. Accessed 3 July 2020.

[4] Nair, Anita. Eating Wasps. Contxt,2018. 